\title{
Differences in lipogenesis and lipolysis in obese and non-obese adult human adipocytes
}

\author{
MARIANA CIFUENTES, CECILIA ALBALA and CECILIA V ROJAS
}

Institute of Nutrition and Food Technology (INTA), Universidad de Chile, Santiago, Chile.

\begin{abstract}
It has been proposed that differences in adipocyte function and/or metabolism between obese and lean individuals may manifest themselves in functional adipose tissue abnormalities that lead to metabolic disorders in obesity. We studied lipogenesis and lipolysis of omental adipocytes from obese (OB) and nonobese (NOB) humans. The specific activity of the lipogenic marker enzyme G3PDH was $50 \%$ lower in total adipocytes of $\mathrm{OB}$ compared to that of NOB subjects. Omental adipocytes from OB subjects also had lower basal lipolytic levels, and a lower lipolytic response to $\beta$-adrenergic stimulus. Cholesterol depletion of adipocyte plasma membrane using methyl b-cyclodextrin caused a lipolytic effect on adipocytes of both groups together, but when obese and lean subjects were analyzed separately, the response was significant only in the obese. We present evidence of a different lipogenic and lipolytic profile in obese individuals' omental adipocytes, and propose a relevant role of plasma membrane cholesterol, where the impact of its removal in $\mathrm{OB}$ and $\mathrm{NOB}$ adipocyte lipolysis differs.
\end{abstract}

Key terms: adipocyte, cholesterol, lipogenesis, lipolysis, obesity, triglyceride metabolism.

\section{INTRODUCTION}

The excess of visceral adipose tissue is linked to numerous health problems. An augmented adiposity is associated with increased fat cell volume. Thus, obese individuals have a relatively large amount of hypertrophic adipocytes compared to lean subjects. Studies on animal and human fat cells have established that several metabolic functions of adipocytes are altered with a larger cell size, such as insulin sensitivity and glucose metabolism, in addition to adipokine secretion and gene expression profiles (Bluher et al., 2004; Salans and Doherty, 1971; Salans et al., 1974; Smith, 1971; Yang et al., 2004). This has led to the suggestion that functional predominance of hypertrophic and/or metabolically-impaired cells in adipose tissue is an important causal effect for a low response of the tissue to homeostatic signals, thus perpetuating or exacerbating the obese state. In order to test this hypothesis, we set out to study in vitro lipogenesis and lipolysis in isolated omental adipocytes from $\mathrm{OB}$ and $\mathrm{NOB}$ adults. Given that lipolysis signaling depends on proteins located in caveolae, and that disrupting the organization of these cholesterol-rich structures has been associated with metabolic alterations in obese adipocytes (Le Lay et al., 2004), we also evaluated the impact of plasma membrane cholesterol removal using methyl $\beta$-cyclodextrin $(\mathrm{M} \beta \mathrm{CD})$ in $\mathrm{OB}$ and NOB adipocyte lipolysis.

The present results underscore a different lipogenic and lipolytic profile between lean and obese subjects. Our data evidences the metabolic relevance of the lower plasma membrane cholesterol content in adipocytes of obese subjects, affecting the physiological regulation of lipolysis. 
MATERIALS AND METHODS

\section{Isolation of Adipocytes}

Human omental fat was obtained from 25 obese (OB) and non-obese (NOB) subjects undergoing elective abdominal surgery (either gastric bypass, gynecological or gastrointestinal). The subjects' age range was 29-79 and their body mass index (BMI) ranged between 18 and $54 \mathrm{~kg} / \mathrm{m}^{2}$. The cutoff point to define obesity was considered according to the NIH definition of BMI $\geq 30$ $\mathrm{kg} / \mathrm{m}^{2}$. Twelve subjects (9 men, 3 women) were NOB (BMI $\left.23.3 \pm 3.4 \mathrm{~kg} / \mathrm{m}^{2}\right)$, whereas 13 were $\mathrm{OB}\left(\mathrm{BMI} 38.2 \pm 4.3 \mathrm{~kg} / \mathrm{m}^{2} ; 4\right.$ men, 9 women). We did not observe any influence of gender in the parameters studied. The protocol was approved by the Institutional Review Board at INTA, University of Chile, and informed consent was signed by the donors. Adipose tissue removed during surgery was immersed in saline solution and transported to the laboratory to be processed within one hour. Upon arrival, the tissue was washed several times with Hanks' Balanced Salt Solution (HBSS), removing all visible connective tissue, blood clots and vessels, and then minced into small pieces (2-3 $\left.\mathrm{mm}^{2}\right)$ and cultured in M199 (Invitrogen, Carlsbad, CA) medium, supplemented with antibiotics (penicillin-streptomycin) at $37^{\circ} \mathrm{C}$ in a controlled atmosphere incubator. There was a 2-day incubation period of the tissue in order to minimize inter-individual variability caused by subject factors such as hormonal milieu, current health status or medications. Adipocytes were isolated using a method based on Rodbell's (1964) work. Briefly, minced adipose tissue was incubated with $1 \mathrm{~g} / 1$ collagenase type I (Worthington Biochemical Corp. Lakewood, NJ) at $37^{\circ} \mathrm{C}$ for $60 \mathrm{~min}$ with continuous mixing. The resulting cell suspension was filtered through a sterile gauze pad, and as adipocytes spontaneously separate from the aqueous phase, they were recovered by gently aspirating the floating layer with a plastic pipette, and washed twice with 5 volumes of HBSS. Isolated adipocytes were either immediately used for lipolysis studies, or frozen for later glycerol-3-phosphate dehydrogenase (G3PDH) determination.
The lipolytic responsiveness to $\beta$ adrenergic stimulus and detection of lipogenic activity (see below) evidenced the presence of viable adipocytes after the digestion of the tissue.

\section{Lipogenesis and Lipolysis}

The synthesis of triglycerides in the adipocyte uses both pre-made and de novomade fatty acids, whereas the glycerol backbone comes from glucose-derived glycerol-3-phosphate. Lipogenic capacity was assessed by the specific activity of the enzyme G3PDH, which catalyzes the formation of the glycerol backbone of triglycerides from dihydroxyacetone phosphate provided via glycolysis. This enzyme is considered rate-limiting for triglyceride synthesis in adipose tissue, given that in this tissue it is the sole source of glycerol-3-phosphate. Its use as a lipogenic marker in mature adipocytes is supported by the upregulation of its mRNA and activity by insulin (Moustaid et al., 1996; Rumberger et al., 2003). Briefly, isolated adipocytes were homogenized (10 strokes at $1800 \mathrm{rpm}$ with a Glas-Col homogenizer system, Glas-Col, IN) using a glass tube equipped with a Teflon pestle, at $4^{\circ} \mathrm{C}$ in a buffer containing $0.25 \mathrm{M}$ sucrose, $1 \mathrm{mM}$ EDTA, $50 \mathrm{mM}$ triethanolamine and $1 \mathrm{mM}$ dithiotreithol. The homogenate was centrifuged at $14,000 \mathrm{x} \mathrm{g}, 4^{\circ} \mathrm{C}$ for $30 \mathrm{~min}$. $\mathrm{G} 3 \mathrm{PDH}$ activity was determined in the supernatant based on the method by Kozak and Jensen (1974), by measuring NADH oxidation (time course of the change in absorbance at $340 \mathrm{~nm}$ at $37^{\circ} \mathrm{C}$ ) on a microplate reader (EL-808, BioTek Instruments Inc., Winooski, VT), using dihydroxyacetone phosphate as substrate for the enzyme. The reaction was linear with respect to time over the period of assay. One unit of enzyme activity corresponds to the oxidation of $1 \mathrm{nmol}$ of $\mathrm{NADH}$ per minute in the conditions indicated above. Protein concentration in the soluble extract was measured using the Bradford method (Bradford, 1976).

Lipolysis was assessed during the 48 hours of adipose culture by the measurement of cumulative glycerol 
released into the M199 culture medium (Free glycerol determination reagent, Sigma, St Louis MO). In addition, the acute lipolytic response to $\beta$-adrenergic stimulus, with or without depletion of plasma membrane cholesterol (60 min preincubation with $10 \mathrm{mM} \mathrm{M} \beta \mathrm{CD}$ [Sigma]), was evaluated by measuring the total glycerol released during a 90-min incubation of $10 \%$ adipocyte suspensions at $37^{\circ} \mathrm{C}$ with gentle continuous swirling and the addition of $10 \mu \mathrm{M}$ isoproterenol (Sigma) or vehicle. For lipolysis assessment during adipose tissue culture, glycerol values are expressed per mg tissue, whereas for lipolysis assay in adipocyte suspensions, values are normalized to total cellular lipids, as described by Carpéné (2001) or, in experiments with lipolytic agents, to the respective basal (non-stimulated) control. Total cellular lipids were extracted using the method by Dole and Meinertz (1960), and determined gravimetrically. In light of a reported independent relationship between cell size and lipolysis that may act as a confounder, especially in our studies comparing $\mathrm{OB}$ and $\mathrm{NOB}$ subjects, expression per mg lipid was considered the most adequate. As shown by Large et al. (1999), glycerol release expressed per lipid content is highly correlated with the activity of hormone sensitive lipase in studies of obese and lean human subjects, and more relevant to lipolytic capacity than per cell number due to the increased fat cell volume in the obese.

\section{Statistics}

The differences between means were analyzed using Student's t test and were considered significant at $\mathrm{p} \leq 0.05$. Pearson's correlation coefficient was used to evaluate the associations for continuous variables. Data are expressed as means \pm SEM.

\section{RESULTS}

\section{Lipogenesis}

The specific activity of the lipogenic enzyme G3PDH was almost half in OB subjects compared to that in adipocytes from NOB ( $<<0.05$, Fig. 1). Consistent with this, there was a significant inverse correlation between the lipogenesis marker and subjects' BMI (Fig. 1, inset, $\mathrm{r}^{2}=0.31$, $\mathrm{p}=0.01)$. It is worth noting that there were no differences in protein concentration (used to normalize G3PDH activity) between $\mathrm{OB}$ and NOB subjects that could have biased these results.

\section{Lipolysis}

The release of glycerol to the incubation medium during culture of whole omental adipose tissue or isolated adipocytes was used as an indicator of lipolytic activity. Both basal and isoproterenol-stimulated lipolysis were lower in isolated adipocytes of OB subjects $(\mathrm{p}<0.05$ and $\mathrm{p}<0.01$, respectively, Fig. 2). Consistent with these observations, there was a highly significant inverse correlation between lipolysis and subject's BMI for whole tissue $\left(\mathrm{r}^{2}=0.46\right.$, $\mathrm{p}<0.0005$, inset, Fig. 2) and isolated adipocytes (basal: $\mathrm{r}^{2}=0.28, \mathrm{p}<0.01 ; \beta$ adrenergic-stimulated: $\mathrm{r}^{2}=0.17, \mathrm{p}<0.05$, $n=20)$. Adipocytes from obese subjects showed a lower response to $\beta$-adrenergic stimulus compared to those from their lean counterparts (Fig. 3, p<0.05).

Exposure of adipocytes to $10 \mathrm{mM}$ $\mathrm{M} \beta \mathrm{CD}$ in a subset of 11 samples caused a significant increase in basal lipolysis. This increase was directly proportional to the subject's BMI $\left(r^{2}=0.5, p<0.05\right.$, Fig. 4). The lipolytic response to $\beta$-adrenergic stimulation was significantly reduced when adipocytes were exposed to M $\beta C D$ (345 \pm $50 \%$ vs. $199 \pm 33 \%$, respectively, $\mathrm{p}<$ $0.05)$. Interestingly, when comparing the effect of $M \beta C D$ versus vehicle, a significant reduction in the lipolytic response to isoproterenol was observed in adipocytes from subjects with BMI $>40 \mathrm{~kg} /$ $\mathrm{m}^{2}$ (morbidly obese, according to the NIH definition), whereas lean subjects showed no significant difference (Fig. 5). Consistent with this, a significant correlation was found between BMI and the ratio of lipolytic response to $10 \mu \mathrm{M}$ isoproterenol in the presence and absence of $10 \mathrm{mM} \mathrm{M} \beta \mathrm{CD}\left(\mathrm{r}^{2}=0.46, \mathrm{p}<0.05\right)$. 


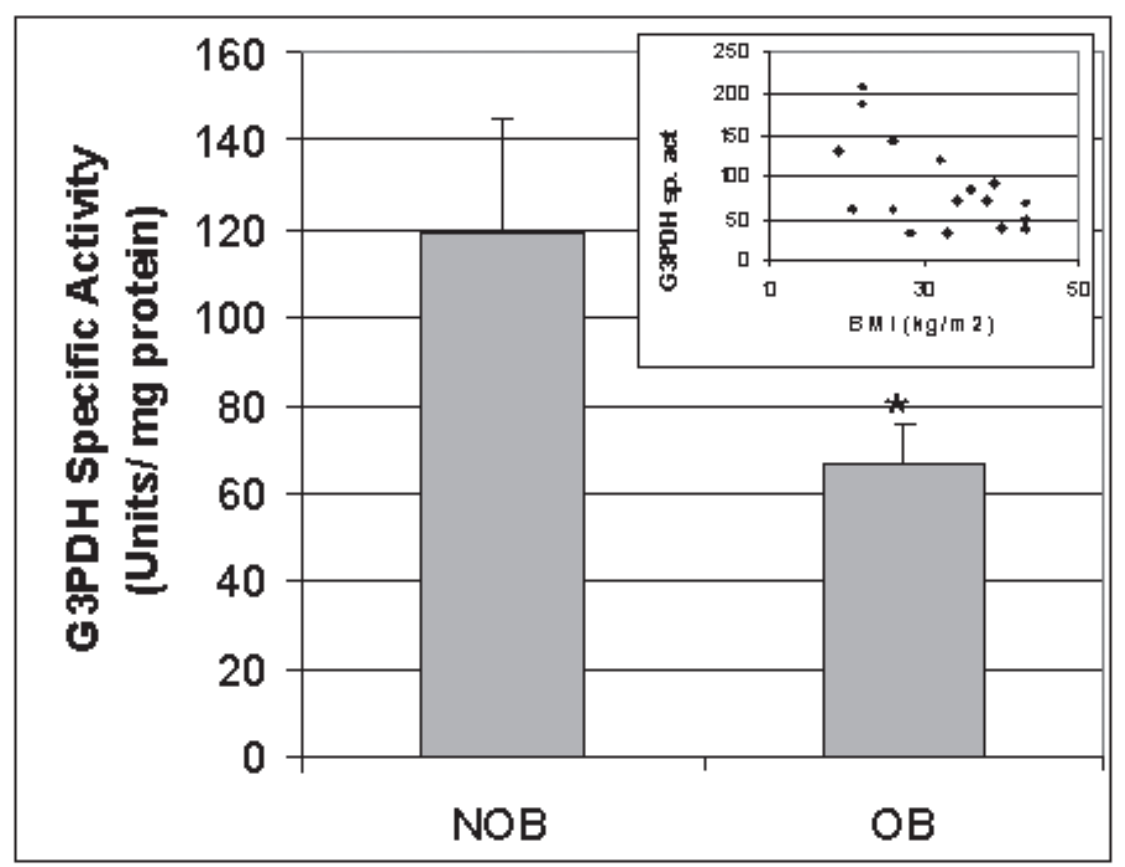

Figure 1: Specific activity of the lipogenic enzyme G3PDH in isolated adipocytes from omental adipose tissue from NOB and OB subjects. Data represent means \pm SEM of 7 NOB and 10 OB subjects. There were no differences in protein concentration between groups. $* \mathrm{p}<0.05$, Student's ttest. The inset shows the correlation between G3PDH specific activity and BMI $\left(\mathrm{r}^{2}=0.31, \mathrm{p}=0.01\right)$

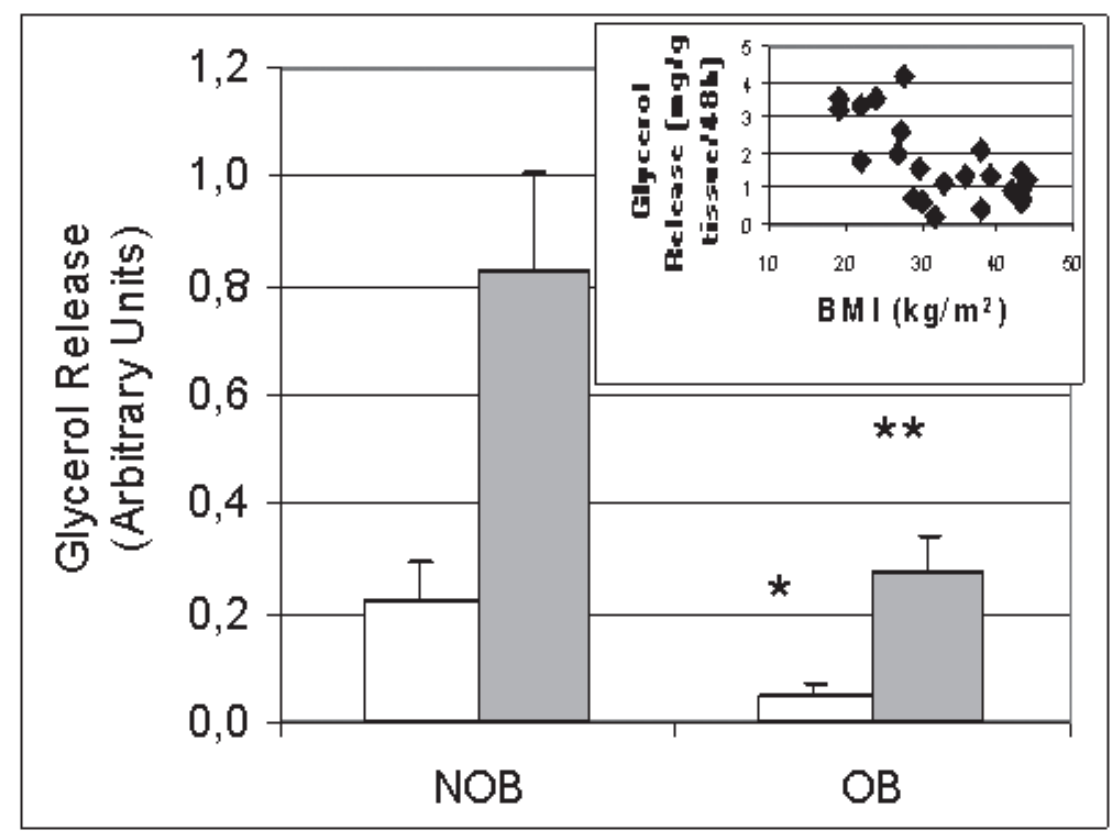

Figure 2: Lipolysis in isolated adipocytes during a 90-min incubation with isoproterenol $10 \mu \mathrm{M}$ (grey bars) or vehicle (white bars) in NOB $(n=10)$ and OB $(n=10)$ subjects. The inset shows the association between adipose tissue lipolysis, measured by the release of glycerol to the incubation medium during $48 \mathrm{~h}$ of tissue culture, and BMI of the donor $\left(\mathrm{r}^{2}=0.46, \mathrm{p}<0.0005\right)$. Bars represent mean \pm SEM of $10 \mathrm{NOB}$ and $10 \mathrm{OB}$ subjects. Significantly different from NOB, $* \mathrm{p}<0.05$; ${ }^{*} \mathrm{p}<0.01$, Student's t-test. Arbitrary units are defined as $\mathrm{mg}$ glycerol $\mathrm{x} \mathrm{mg} \mathrm{cell} \operatorname{lipid}^{-1} \mathrm{x} 90 \mathrm{~min}^{-1}$. 


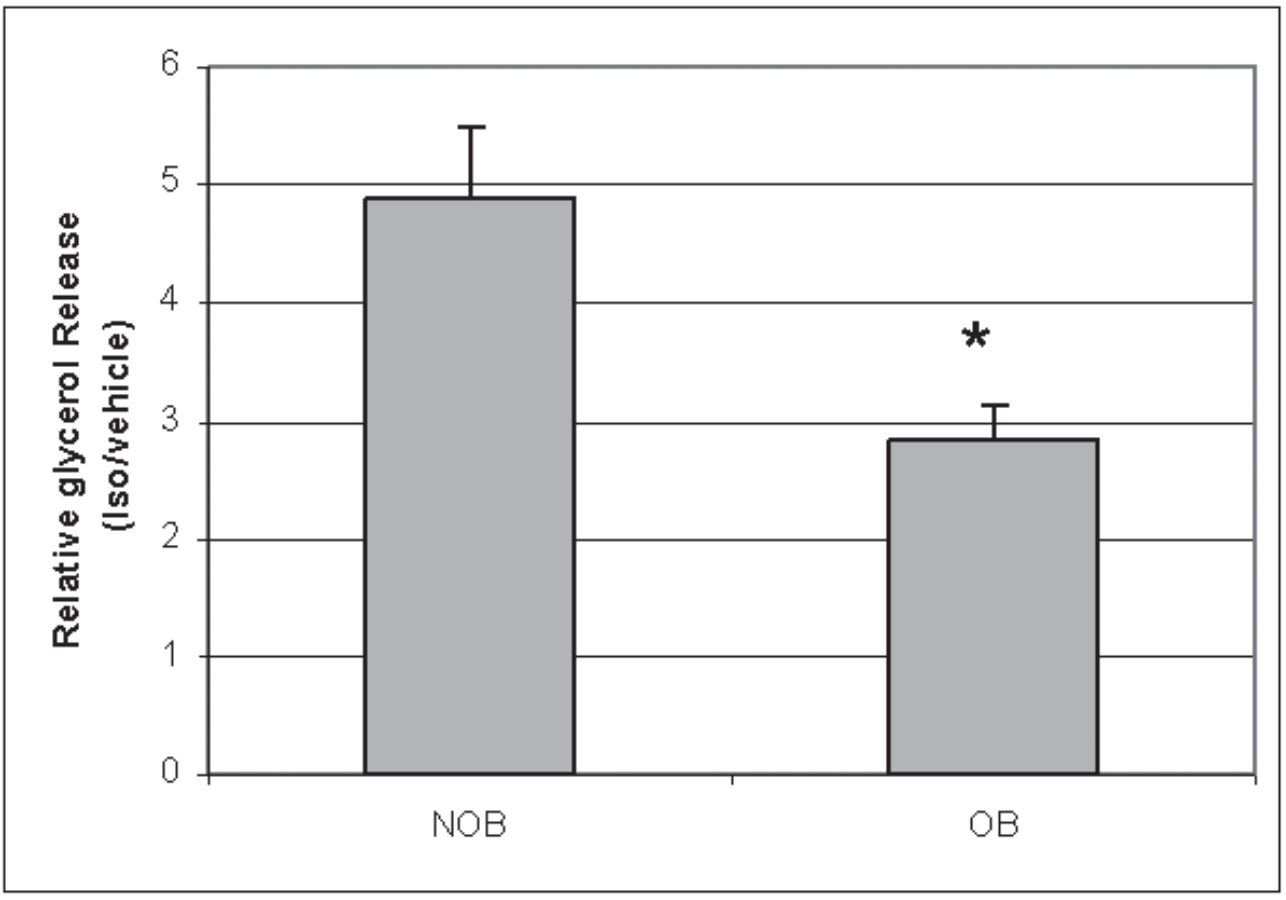

Figure 3: Isoproterenol-stimulated lipolysis in isolated adipocytes from NOB $(n=6)$ and OB $(n=6)$ subjects during $90-\mathrm{min}$ incubation with $10 \mu \mathrm{M}$ isoproterenol. The release of glycerol is expressed as the percentage of each subject's basal lipolytic activity. Bars represent mean \pm SEM. Significantly different from NOB, ${ }^{*} \mathrm{p}<0.05$; Student's t-test.

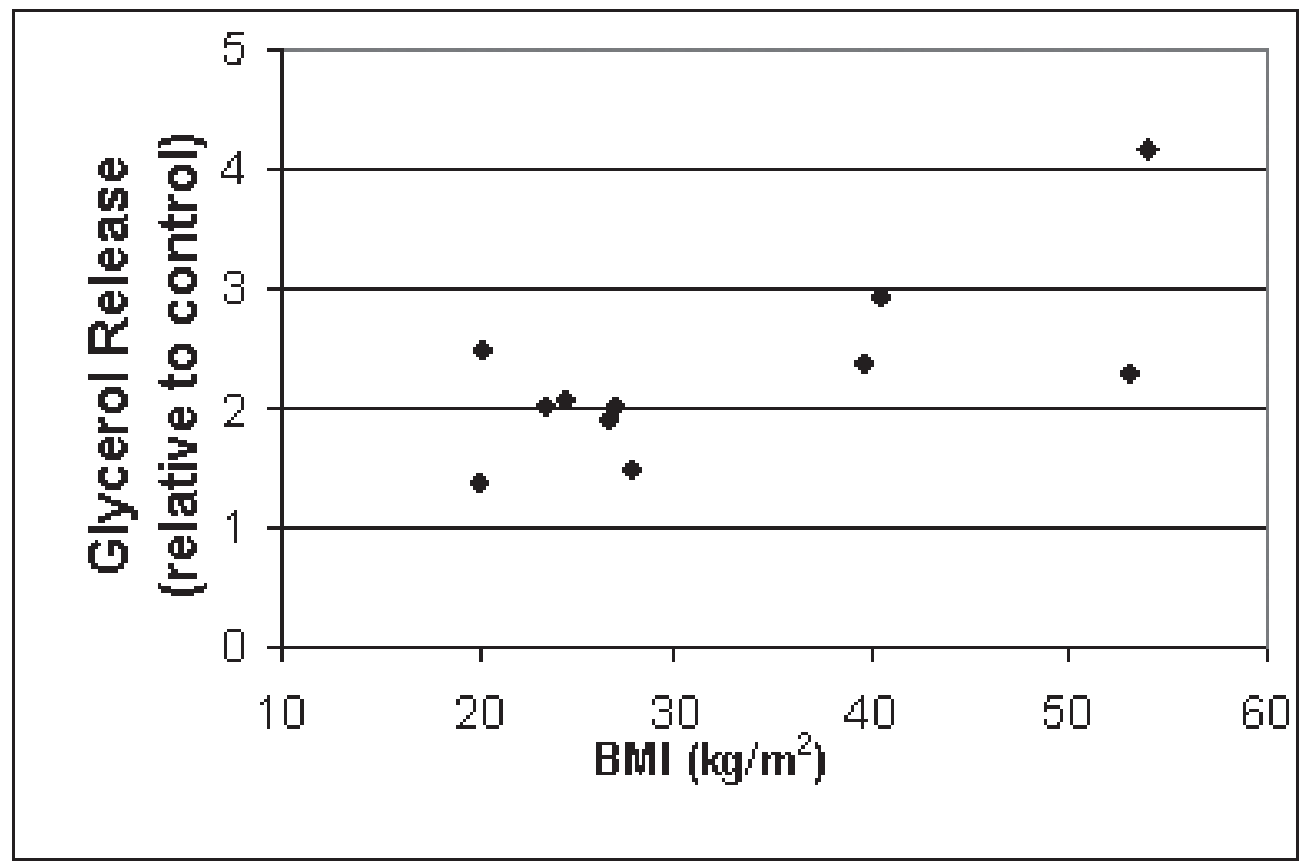

Figure 4: Direct association between lipolysis in $\mathrm{M} \beta C D(10 \mathrm{mM})$-treated adipocytes and BMI of the donor $\left(\mathrm{r}^{2}=0.50, \mathrm{p}=0.01, \mathrm{n}=11\right)$. Glycerol release is expressed relative to control values (without $\mathrm{M} \beta \mathrm{CD})$. 


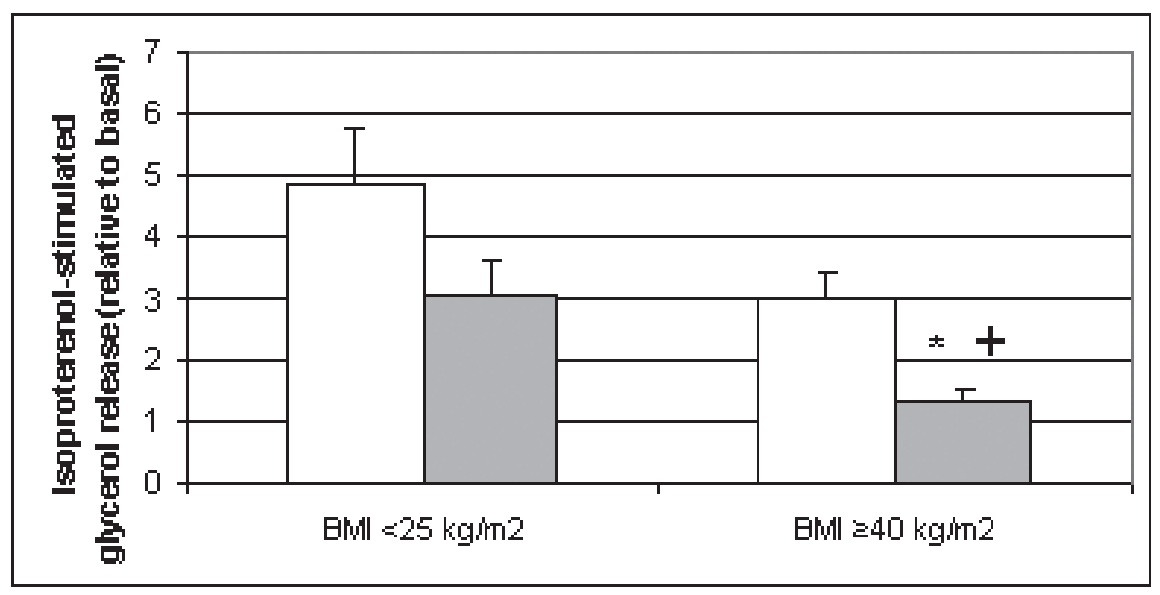

Figure 5: Isoproterenol $(10 \mu \mathrm{M})$-stimulated glycerol release in $\mathrm{M} \beta \mathrm{CD}$-pretreated adipocytes (10mM, grey bars) and vehicle controls (white bars), in subjects with BMIs $<25$ and $\geq 40 \mathrm{~kg} / \mathrm{m}^{2}$. Data are means \pm SEM of 8 subjects ( 4 each group). ${ }^{*} \mathrm{p}=0.05$ vs $\mathrm{BMI}<25$ group, ${ }^{\dagger} \mathrm{p}<0.05$ vs. vehicle control.

\section{DISCUSSION}

In the present work, we studied lipogenesis and lipolysis in adipocytes isolated from omental adipose tissue of $\mathrm{OB}$ and $\mathrm{NOB}$ adults within a wide range of BMI (18-54 $\left.\mathrm{kg} / \mathrm{m}^{2}\right)$. Our observations show that the specific activity of the lipogenesis marker G3PDH in the OB was half of that in the adipocytes of their NOB counterparts. On the other hand, higher BMIs were associated with lower basal and $\beta$ adrenergic-stimulated lipolysis and a greater sensitivity to plasma membrane signaling impairment due to cholesterol removal. A larger triglyceride accumulation in the OB adipocyte may be related to the lower lipolytic activity that we observed in this group, as others have also proposed (Langin et al., 2005). In addition, the lower G3PDH specific activity that we found in the $\mathrm{OB}$, which may result counterintuitive, could represent a decreased capacity to store the excess circulating triglycerides, likely to result in hypertriglyceridemia and fat accumulation in other regions of the body, with the known detrimental effects associated with the metabolic syndrome.

Using an in vivo approach in humans, Dodt et al. (2003) observed a blunted lipolytic response to intraneural stimulation in obese females, which is consistent with our in vitro results and supports the notion that obesity may be at least in part associated with a low lipolytic response to sympathetic activation. In accordance, Gómez-Ambrosi et al. (2004) studied the pattern of gene expression of omental adipose tissue and showed that obese subjects had lowered and enhanced expression of lipolysis inducer and repressor genes, respectively.

There is considerable discrepancy in the literature regarding lipolysis data normalization. Given the reported direct relationship between adipocyte cell size and lipolysis (Large et al., 1999), and the greater relative abundance of larger adipocytes in the obese (Large et al., 1999), adipose tissue is expected to show greater unadjusted lipolysis among the obese than among NOB individuals. Thus, to avoid a confounding factor due to different cell size distribution in OB versus NOB, our glycerol release values were normalized by expressing them per $\mathrm{mg}$ of total lipid, thus assessing lipolytic activity for a given lipid mass. Supporting this, studies of obese and lean humans have observed a high correlation between the activity of the key lipolytic enzyme HSL (hormone sensitive lipase) and adipocyte glycerol release expressed per lipid content (Large et al., 1999). The authors stated that lipid content 
is more relevant to lipolytic capacity than normalization per cell number, due to the increased fat cell volume in the obese. It is worth noting that $\beta$-adrenergic stimulation over basal conditions also proved to be lower in OB subjects, and this assessment is independent of cell size or number, given that it is normalized with the corresponding control (each basal value).

The role of membrane cholesterol content for caveolae integrity, specific signal transduction and proper cell function has already been recognized (Le Lay et al. 2001). It has been shown that hypertrophic adipocytes have an impaired metabolism, together with lower plasma membrane cholesterol content (Le Lay et al. 2001). Our observations expand those by Le Lay et al. $(2001,2004)$ who showed that cholesterol depletion in adipocytes induces insulin resistance and changes in the expression of a number of genes relevant for adipose metabolism. These results were provided as evidence of cholesterol reduction in plasma membrane as a link between adipocyte hypertrophy and metabolic impairment, which is supported by our present results. Our experiments exposing adipocytes to $\mathrm{M} \beta \mathrm{CD}$ caused a significant increase in basal lipolysis (expected after altering plasma membrane caveolae integrity, resulting in a decreased phosphodiesterase $3 \mathrm{~B}$ activity [Nilsson et al., 2006]) and consequently, in a reduced lipolytic response to the $\beta$-adrenergic stimulus. Interestingly, we observed a significant association between the impact of $\mathrm{M} \beta \mathrm{CD}$ on basal lipolysis and BMI. Moreover, the significant correlation between BMI and the ratio of isoproterenol to basal lipolysis in presence and absence of $\mathrm{M} \beta \mathrm{CD}$ support a greater susceptibility of adipocytes from obese subjects to cholesterol depletion-driven plasma membrane altered signalling.

Enlarged fat cells, known to be more abundant as subjects' BMI increase (Julien et al., 1989; Salans et al., 1973; Van Harmelen et al., 2003) are insulin resistant (Olefsky 1977) and show a distinct secretion pattern that has linked them to obesity-associated disorders (Imbeault et al., 1999; Van Harmelen et al., 2000).
Interestingly, the adipose tissue-specific insulin receptor knockout mice (Bluher et al., 2004) show polarization of adipocytes into two subpopulations of small $(<50 \mu \mathrm{m}$ diameter) and large $(>100 \mu \mathrm{m})$ cells, which is accompanied by differences in triglyceride synthesis and lipolysis, among other parameters. The observations here reported show intrinsic differences in triglyceride metabolism between omental adipocytes from $\mathrm{OB}$ and NOB subjects, and we propose that the enrichment in hypertrophied and membrane cholesteroldeprived adipocytes may be driving such alterations. It is possible that the impaired lipolytic response contributes in time to the enlargement of the triglyceride depot. The reduced ability to store additional triglycerides, would result in an increased amount of circulating lipids, elevating the risks associated with the metabolic syndrome.

To the best of our knowledge, no other study has evaluated lipogenesis and lipolysis in omental adipocytes from human $\mathrm{OB}$ and NOB subjects. The present work shows relevant differences in omental adipocyte triglyceride metabolism in obese compared to non-obese subjects and suggest that obese individuals' adipocytes are more susceptible to plasma membrane reduced cholesterol content. Even though we intended to minimize subject factors, we cannot rule out that comorbidities present in obese subjects may be influencing the different behaviour of the fat cells. The comparison of triglyceride handling between these groups and in a fat depot of such pathogenic relevance helps in understanding differences in metabolism and responsiveness, which may be target for pharmacological intervention and require further studies.

\section{ACKNOWLEDGMENTS}

We would like to thank Dr. Miguel A. Celis at Tisné Hospital, Dr. Leonardo Rodríguez at DIPRECA Hospital and Drs. Cristián Cavalla, James Hamilton and Gonzalo Wiedmaier at Padre Hurtado Hospital for the invaluable help in obtaining fat tissue, 
as well as Mrs. Marisol Blanco and Mr. Rodrigo Brücher for their technical assistance.

\section{GRANT SUPPORT}

Supported by grants from DI-U de Chile $\left(\mathrm{N}^{\mathrm{o}} \mathrm{S}\right.$ Mult 04/06-2 to C. Rojas and I-04/012 to $\mathrm{M}$. Cifuentes), and FONDECYT $\left(\mathrm{N}^{\mathrm{o}}\right.$ 1070632 to C. Rojas, $\mathrm{N}^{\circ} 1080232$ to $\mathrm{M}$. Cifuentes).

\section{REFERENCES}

BLUHER M, WILSON-FRITCH L, LESZYK J, LAUSTSEN P G, CORVERA S, KAHN CR (2004) Role of insulin action and cell size on protein expression patterns in adipocytes. J Biol Chem 279: 31902-31909.

BRADFORD MM (1976) A rapid and sensitive method for the quantitation of microgram quantities of protein utilizing the principle of protein-dye binding. Anal Biochem 72: 248-254.

CARPÉNÉ C (2001) Assays of adrenergic receptors including lipolysis and binding measurements. In: AILHAUD G (ed) Adipose Tissue Protocols. New Jersey: Humana Press. pp. 129-140.

DODT C, LONNROTH P, WELLHONER JP, FEHM HL, ELAM M (2003) Sympathetic control of white adipose tissue in lean and obese humans. Acta Physiol Scand 177: 351-357.

DOLE VP, MEINERTZ H (1960) Microdetermination of long-chain fatty acids in plasma and tissues. J Biol Chem 235: 2595-2599.

GÓMEZ-AMBROSI J, CATALÁN V, DIEZ-CABALLERO A, MARTÍNEZ-CRUZ LA, GIL MJ, GARCÍAFONCILLAS J, CIENFUEGOS JA, SALVADOR J, MATO JM, FRUHBECK G (2004) Gene expression profile of omental adipose tissue in human obesity. FASEB J 18: 215-217.

IMBEAULT P, LEMIEUX $S$, PRUDHOMME D, TREMBLAY A, NADEAU A, DESPRES JP, MAURIEGE P (1999) Relationship of visceral adipose tissue to metabolic risk factors for coronary heart disease: is there a contribution of subcutaneous fat cell hypertrophy? Metabolism 48: 355-362.

JULIEN P, DESPRES JP, ANGEL A (1989) Scanning electron microscopy of very small fat cells and mature fat cells in human obesity. J Lipid Res 30: 293-299.

KOZAK LP, JENSEN JT (1974) Genetic and developmental control of multiple forms of L-glycerol 3-phosphate dehydrogenase. J Biol Chem 249: 7775 7781 .

LANGIN D, DICKER A, TAVERNIER G, HOFFSTEDT J, MAIRAL A, RYDEN M, ARNER E, SICARD C, JENKINS M, VIGUERIE N, VAN HARMELEN V, GROSS RW, HOLM C, ARNER P (2005) Adipocyte lipases and defect of lipolysis in human obesity. Diabetes 54: 3190-3197.

LARGE V, REYNISDOTTIR S, LANGIN D, FREDBY K, KLANNEMARK M, HOLM C, ARNER P (1999)
Decreased expression and function of adipocyte hormone-sensitive lipase in subcutaneous fat cells of obese subjects. J Lipid Res 40: 2059-2066.

LE LAY S, KRIEF S, FARNIER C, LEFRERE I, LE LIEPVRE X, BAZIN R, FERRE P, DUGAIL I (2001) Cholesterol, a cell size-dependent signal that regulates glucose metabolism and gene expression in adipocytes. J Biol Chem 276: 16904-16910.

LE LAY S, FERRE P, DUGAIL I (2004) Adipocyte cholesterol balance in obesity. Biochem Soc Trans 32: 103-106.

MOUSTAID N, JONES BH, TAYLOR JW (1996) Insulin increases lipogenic enzyme activity in human adipocytes in primary culture. J Nutr 126: 865-870.

NILSSON R, AHMAD F, SWARD K, ANDERSSON U, WESTON M, MANGANIELLO V, DEGERMAN E (2006) Plasma membrane cyclic nucleotide phosphodiesterase 3B (PDE3B) is associated with caveolae in primary adipocytes. Cell Signal 18: 17131721 .

OLEFSKY JM (1977) Mechanisms of decreased insulin responsiveness of large adipocytes. Endocrinology 100: $1169-1177$.

RODBELL M (1964) Metabolism of isolated fat cells. I. Effects of hormones on glucose metabolism and lipolysis. J Biol Chem 239: 375-380.

RUMBERGER JM, WU T, HERING MA, MARSHALL S (2003) Role of hexosamine biosynthesis in glucosemediated up-regulation of lipogenic enzyme mRNA levels: effects of glucose, glutamine, and glucosamine on glycerophosphate dehydrogenase, fatty acid synthase, and acetyl-CoA carboxylase mRNA levels. J Biol Chem 278: 28547-28552.

SALANS LB, DOUGHERTY JW: The effect of insulin upon glucose metabolism by adipose cells of different size (1971) Influence of cell lipid and protein content, age, and nutritional state. J Clin Invest 50: 1399-1410.

SALANS LB, CUSHMAN SW, WEISMANN RE (1973) Studies of human adipose tissue. Adipose cell size and number in nonobese and obese patients. J Clin Invest 52: $929-941$

SALANS SB, BRAY GA, CUSHMAN SW, DANFORTH JR E, GLENNON JA, HORTON ES, SIMS EA (1974) Glucose metabolism and the response to insulin by human adipose tissue in spontaneous and experimental obesity. Effects of dietary composition and adipose cell size. J Clin Invest 53: 848-856.

SMITH U (1971) Effect of cell size on lipid synthesis by human adipose tissue in vitro. J Lipid Res 12: 65-70.

VAN HARMELEN V, SKURK T, ROHRIG K, LEE YM, HALBLEIB M, APRATH-HUSMANN I, WEYER C, FOLEY JE, BOGARDUS C, TATARANNI PA, PRATLEY RE (2000) Enlarged subcutaneous abdominal adipocyte size, but not obesity itself, predicts type II diabetes independent of insulin resistance. Diabetologia 43: 1498-1506

VAN HARMELEN V, SKURK T, ROHRIG K, LEE YM, HALBLEIB M, APRATH-HUSMANN I, HAUNER H (2003) Effect of BMI and age on adipose tissue cellularity and differentiation capacity in women. Int $\mathrm{J}$ Obes Relat Metab Disord 27: 889-895.

YANG X, JANSSON PA, NAGAEV I, JACK MM, CARVALHO E, SUNNERHAGEN KS, CAM MC, CUSHMAN SW, SMITH U (2004) Evidence of impaired adipogenesis in insulin resistance. Biochem Biophys Res Commun 317: 1045-1051. 